
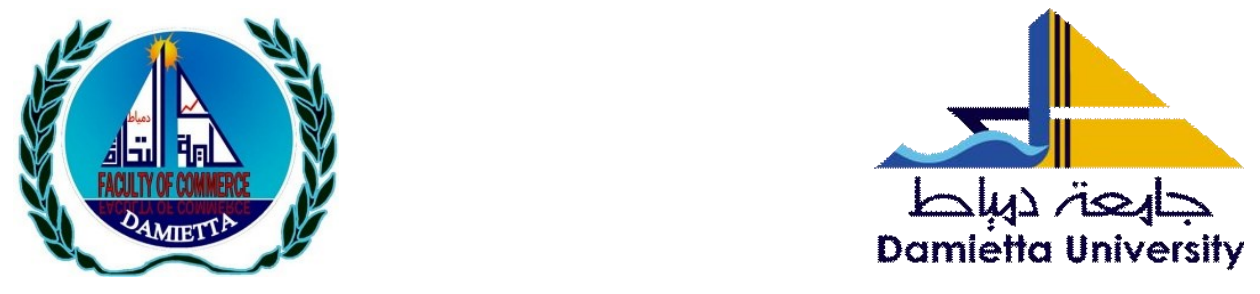

\title{
Entrepreneurship and SMEs Sustainable Development through Business Incubators: The case of Oman
}

\author{
By \\ Dr. Hesham Magd \\ Dr. Aiman El Gharib \\ Associate Dean - Quality \\ Assistant Professor, Higher \\ Assurance \& Accreditation and \\ Institute for Computer and \\ Faculty of Business and \\ Economics Head Modern College \\ of Business \& Science (MCBS), \\ Muscat, Oman, \\ Business Administration, \\ Damietta, Egypt, \\ A.farouk@za.edu.eg \\ Hesham.Magd@,mcbs.edu.om
}

Scientific Journal for Financial and Commercial Studies and Researches (SJFCSR)

Faculty of Commerce - Damietta University

Vol.2, No.2, Part 2., July 2021

APA Citation:

Magd, H. and El Gharib, A. (2021). Entrepreneurship and SMEs Sustainable Development through Business Incubators: The case of Oman, Scientific Journal for Financial and Commercial Studies and Research, Faculty of Commerce, Damietta University, 2(2)1, pp.191-220.

Website: https://cfdj.journals.ekb.eg/ 
Scientific Journal for Financial and Commercial Studies and Researches

(Vol.2, No.2 Part1, July 2021)

Dr. Hesham Magd and Dr. Aiman El Gharib

\begin{abstract}
Oman's developing economy has relied heavily on hydraulics for its expenditure since the early 1970s. However, due to the current business environment and the new direction of the country; the 2020 and 2040 vision tends to focus on transforming the country into an economy which relies on new sector development, new entrepreneurial business startups and SMEs. Entrepreneurial startups and SMEs are significant factors in the development of sustainable growth of a national economy and it is expected that entrepreneurship in Oman will contribute greatly in its economic development and sustainability. This is since using SMEs to increase diversification in the economy, consequently, results in an increase of job opportunities. A startup entity tends to face several hurdles and challenges during the various stages of development such as rigid labor regulations, business knowledge, networks, attracting market segmentation, raising funds, procuring and operations, people management, policies and regulations and social culture.

These challenges tend to arise because there is a lack of support for both business and for an existing entrepreneurial ecosystem. Business incubators can play a crucial role in developing an effective and supportive entrepreneurial ecosystem to support entrepreneurs in building their startups at different stages. The introduction of business incubators has the potential to help foster entrepreneurial talent as well as creating an environment for entrepreneurship; this is reflective of business incubators being tools at both the micro and macro level. Therefore, Business Incubation is viewed as a combination of business development processes, infrastructure and knowledgeable business experts - designed to nurture and grow startups.
\end{abstract}


Somewhere in the region of 7000 business incubators exists around the world in 2020, according to the National business Incubation Association. The aim of this paper is to showcase how business incubators may be capable of playing a critical role in developing the entrepreneurial ecosystem within Oman. Furthermore, the authors will show how our understanding of business incubators function may help with national development. After considerable review of business incubators where it was concluded that business incubators represent the cornerstone of entrepreneurship and economic development and sustainability in any economy and especially in Oman.

For example, the current study concluded that business incubators lead to job creation, new business formation, business stabilization and expansion, commercialization of research and knowledge and business sustainability. All these benefits in turn will lead to economic development and sustainability, and in sustaining such benefits, there are certain critical success factors must be followed for the success of business incubators and they are having stringent incubate selection criteria; access to facilities and resources; access to consultant, advisors, and experts; access to regulations and legal framework; selection of quality of entrepreneurs, performance measurement and acceptance of innovative products or services.

Keywords - Entrepreneurial Ecosystem, Business Incubation, Oman, and Sustainable Development. 
Scientific Journal for Financial and Commercial Studies and Researches

(Vol.2, No.2 Part1, July 2021)

Dr. Hesham Magd and Dr. Aiman El Gharib

\section{INTRODUCTION}

In today's environment nations are seeking to achieve market competitiveness, organizational sustainability and economic growth in emerging and successful economies. One effective approach for achieving this strategy is through the development of entrepreneurship. Maroufkhani, et al., (2017) explain further that the entrepreneur is a driven individual who can find new factors or innovative elements to develop new products or services and contribute to economic development. Cha \& Bae (2010) defined entrepreneurship as a pioneering process that results in the creation of new products and services as well as providing innovative solutions to existing problems. Kuratko \& Kruetts (2004) indicated five key characteristics required for entrepreneurship, and these are: Taking calculated risk; Building, leading and managing a team; Ability to manage resources effectively; Mastering the art of drafting business plan; and Opportunity Recognition. This perspective is called 'Entrepreneurial Perspective' and the functioning assumption is that it can be taught to others (Kuratko, 2005). Other benefits of promoting entrepreneurship were established by Magd \& McCoy (2014), such benefits include product/service innovation, and creativity, and such benefits led to the offerings of entrepreneurship education programs/courses (Karimi et al., 2014).

Consequently, entrepreneurs would require a favorable and supportive environment to thrive and flourish. The notion of this favorable environment is reflected in the development of a supportive ecosystem. Business incubators can play a crucial role in developing an effective and supportive entrepreneurial ecosystem to support entrepreneurs in building their startup ventures at different stages. At a micro level business incubator hold the potential to create and develop entrepreneurial talent and innovation, as well as fostering environments suitable for entrepreneurship at the macro level. 
Scientific Journal for Financial and Commercial Studies and Researches

(Vol.2, No.2 Part1, July 2021)

Dr. Hesham Magd and Dr. Aiman El Gharib

The main aim of this paper is to focus on the critical role that business incubators play in Oman and their role in building a successful entrepreneurial ecosystem led to economic sustainability. In achieving the goal of this paper, it was decided to divide the paper into the following sections:

Section 2 offers a brief on the economy of Oman and its vision for transformation and diversification and the movement towards entrepreneurship where SMEs sector can be developed and nurtured. Section 3 focuses on an overview of business incubators and its meaning as a support mechanism for the development of entrepreneurship and SMEs. Section 4 provides a closer and historical look at business incubators, different types of business incubators, and its impact on economic development and its impact on SMEs. Finally, section 5 investigates the available business incubators in Oman in support of the growing number of incubators in Oman in support of the country's strategy of diversification into entrepreneurship. A closer look is offered on the critical success factors required for the success of business incubators that may lead to economic development. This section also offers a conceptional model for economic development based on business incubators data presented throughout the earlier sections

\section{OVERVIEW OF THE ECONOMY}

Over the past 50 years, Oman's economy was dependent on oil and gas resources. This focus is now under restructuring; where a gradual shift to an economy that relies more on private initiative, national labor and renewable resources is needed - which is part of the 2020 and 2040 vision for Oman. A new strategy of ambitious diversification plans is emerging which focus on transforming the country into an economy which relies on new sector development such as manufacturing, logistics, tourism, mining 
and fisheries, technology, new entrepreneurial startups and SMEs. In support of this, Table 1 indicates that the private sector contributes approximately $38 \%$ of nominal GDP to Oman's economy, while the government's dependency to spend on oil and gas production has declined since 2016 by $4 \%$.

For full implementation of the diversification plans as per the government vision, there needs to be further increases in the private sectors contributions to GDP. Looking closely at Table 1 - which indicates that the government remains highly dependent on oil and gas production - will inform on the strategies required to enable the diversification plans to take effect and focus on increasing diversification activities to aid the economy (Oxford Business Group, 2018). In doing so, Oman is now focusing on the development of a stronger, capable, knowledgeable and talented workforce through improving the skillset of the Omani workforce; making the economy less reliant on expatriates. Table 2 highlights the following observations:

- $54 \%$ of the population is either below the age of 19 or above the age of 55 and are outside the working age demographics

- $46 \%$ of the population are between the working age of 20 to 54 , with $28 \%$ aged between $20-34$. 
Scientific Journal for Financial and Commercial Studies and Researches

(Vol.2, No.2 Part1, July 2021)

Dr. Hesham Magd and Dr. Aiman El Gharib

Table 1: Nominal GDP Percentages in Oman

\begin{tabular}{|l|c|c|c|c|}
\hline Economic Activity & $\mathbf{2 0 1 7}$ & $\mathbf{2 0 1 6}$ & $\mathbf{2 0 1 5}$ & $\begin{array}{c}\text { \% } \\
\text { Progress }\end{array}$ \\
\hline Oil \& Gas Production & $29 \%$ & $26 \%$ & $33.1 \%$ & $-4.1 \%$ \\
\hline Agriculture \& Fisheries & $2.3 \%$ & $2.3 \%$ & $2 \%$ & $2.0 \%$ \\
\hline $\begin{array}{l}\text { Industry Activities - mining, manufacturing, electricity } \\
\text { \& water, building \& construction }\end{array}$ & $20.5 \%$ & $21.4 \%$ & $220.7 \%$ & $-0.2 \%$ \\
\hline $\begin{array}{l}\text { Services Activities - financial intermediation, wholesale } \\
\text { \& retail, real estate, transport, hotels \& restaurants, } \\
\text { education, health }\end{array}$ & $38.6 \%$ & $39.5 \%$ & $37.4 \%$ & $1.2 \%$ \\
\hline \begin{tabular}{l} 
Public Administration \& Defense \\
\hline
\end{tabular} & $13 \%$ & $14 \%$ & $12 \%$ & $1 \%$ \\
\hline
\end{tabular}

Source: National Centre for Statistics and Information, 2018

In 2018, the National Centre for Statistics and Information revealed that 438,862 Omanis are engaged in work in both the public and private sector. Based on this data, it was further highlighted that this amount of the Omani workforce represents $38 \%$ of the Omani employment, with potentially $62 \%$ (this rate of unemployment is offered by the National Centre for Statistics and Information and anyone who is seeking employment and do not have a job is considered unemployed) unemployed representing over a half a million. This is an alarming rate of unemployment which requires immediate attention from the government regarding training, job creation and Omanization to be addressed in the new 2040 vision policy document. It is believed that one strategy which is being utilized in Oman to overcome this rate of unemployment is the promotion of Entrepreneurial cultures and SMEs startups through building a sustainable entrepreneurial ecosystem with business incubators. Mazzarol (2014) has emphasized the importance of government intervention in formulating policies that focus on the development of the private sector(s). 
Scientific Journal for Financial and Commercial Studies and Researches

(Vol.2, No.2 Part1, July 2021)

Dr. Hesham Magd and Dr. Aiman El Gharib

Table 2: Oman Population by Age Group

\begin{tabular}{|c|c|c|}
\hline Age Group & Total & Percentage \\
\hline 0 to 19 & $1,138,566$ & $45 \%$ \\
\hline $20-34$ & 711,245 & $28 \%$ \\
\hline $35-54$ & 447,393 & $18 \%$ \\
\hline 55 to 64 & 101,308 & $4 \%$ \\
\hline $65+$ & 106,857 & $4 \%$ \\
\hline
\end{tabular}

Source: National Centre for Statistics and Information, 2018

\section{BUSINESS INCUBATORS}

The concept of business incubators originated from the USA in the early 1950s, however it started to grow in the 1980s and gain popularity across the globe in the late 1990s (Al Mubaraki and Busler, 2012). Business incubators have been proven to be powerful tools in the support of creating and developing SMEs, innovation and start-ups. In the time they have been in increasing use, business incubators have been recognized and evidenced to meet a variety of economic and socioeconomic needs which include but are not limited to; the creation of wealth and employment, the promotion of innovation and technology transfer. Depending on local and national needs required for the incubator(s) to fulfil, and by extension their structure and function(s) - the support they can offer will vary. In practice, business incubators which are wellstructured will provide critical services, products and resources needed to enable the development, growth and endurance of small businesses. Despite the differing types of business incubators, they are usually similar in nature to one another in the processes and services they make use of (United Nations Industrial Development Organization, 1999:85). 
As previously alluded to, the purpose of business incubators is to provide the necessary services and resources to ensure that entrepreneurs, start-ups and SMEs can progress and become the backbone of the economy. These business incubators allow for a defined set of services to be provided - the first set of services is related to providing functional and fiscal resources i.e., access to financial support, necessary facilities, workspaces and equipment. In addition, the latter half are soft services such as legal, educational, professional development support. This can include but is not limited to; legal advice, networking, coaching and mentoring (UKBI, 2011; Aernoudt, 2004).

It cannot be disputed that during the start-up period, SMEs face a great deal of challenges and unavoidable difficulty in the process of trying to bring their business(es) to life (United Nations Industrial Development Organization, 1999:85). The challenges to their growth and sustainability which start-ups and SMEs face in the current business environment include both labor and market regulations, lack of / exhausted resources, lack of R\&D infrastructure, a lack of capital for business start-ups and a need to find the right market for products (Shanfari, 2012). The obvious and critical solution to these challenges is the introduction of the business incubator which facilitates SMEs and start-ups in the new venture process and allows for technical development and sustainable growth. As defined in a report in 2012 by the UKBI, a Business Incubator provides for the creation of entrepreneurial and innovative firms by providing space and assistance. According to Samsonova (1997:84), the role of business incubators goes far beyond functioning as a landlord advisor. Albert and Gaynor (2001:6) further defined the incubator as a "collective and temporary place for accommodating companies which offers space, assistance and services suited to the needs of companies being launched or recently founded". They went on to identify and clarify the four major characteristics of the Business Incubator. These definitions support the holistic view and characteristics/features of business incubators provided by Markley and McNamara, (1996): 
- Providing spaces such as offices and workshops for rent at below market prices and with flexible terms

- Providing administrative and technical support services

- Providing consulting / business planning for both start-ups and SMEs

Overall, the definition of business incubators can be summarized as a support processes/services for businesses (primarily entrepreneurs, start-ups and SMEs) that aid the development of entrepreneurial firms and support the economy by offering different products and services (UKBI 2012). These services are commonly developed by incubator management to be offered in both the incubator and through its network(s). The main aim of a business incubator is to produce successful ventures that will be financially viable and freestanding, without the support of the program. The provision of management guidance, technical assistance and consultation which has been tailored to fledgling companies is critical to the definition of an incubator (NBIA, 2009 cited in Al Mubaraki and Busler, 2012: 344). It is imperative to highlight the evolution of business incubators since the 1980s until present day, in order to evaluate how it has progressed over the years. The evolution is classified into three phases where it started with affordable space and shared facilities until it reached full-service provisions (see Figure 1).

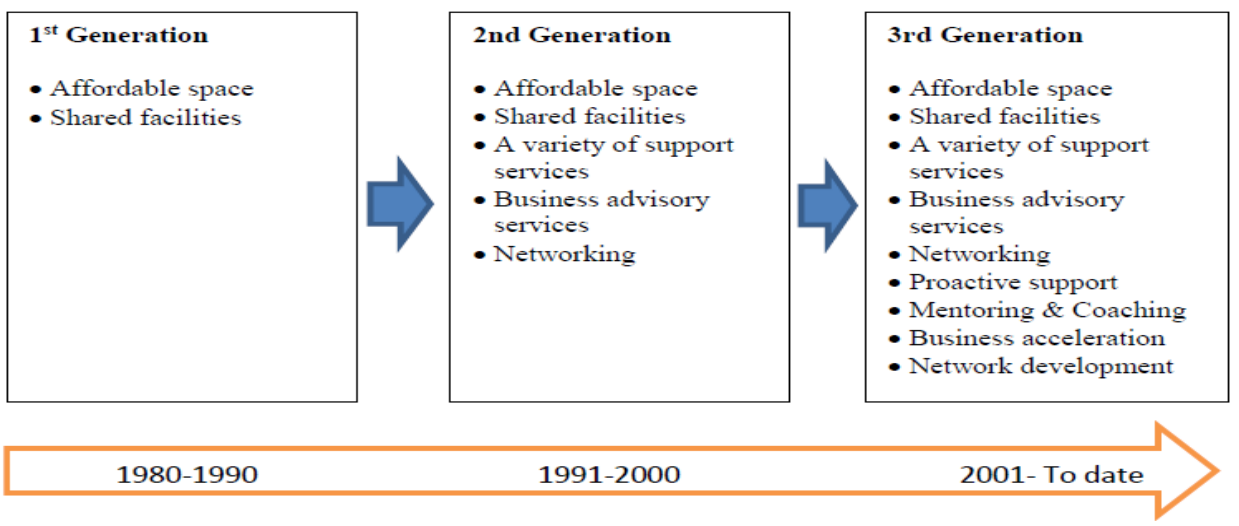

Figure 1: Evolution of Business Incubator

(Source: Theodorakopoulos et al., 2014: 6) 
Scientific Journal for Financial and Commercial Studies and Researches

(Vol.2, No.2 Part1, July 2021)

Dr. Hesham Magd and Dr. Aiman El Gharib

\section{BUSINESS INCUBATORS AND ECONOMIC DEVELOPMENT}

It is widely recognized that business incubators play a vital role in contributing to the country's economy on a local, regional, national and global level (Campbell, 1989; AL Mubaraki, 2008; Ndabeni, 2008; Al Mubaraki et al., 2010; Dee et al., 2011; Lewis et al., 2011; Lose et al., 2016). Business Incubators have a positive impact on economic development and sustainability through job creation across different countries such as Oman, USA, China and Europe (Sanyal and Hisam, 2018; Wagner, 2006; Lalkaka, 2002; Ogutu and Kihonge, 2016). Moreover, Mahmood et al., (2015) and Markley and McNamara (1995) further confirmed that business incubators played a crucial role in creating, nurturing and sustaining SMEs in the local economy and in turn developing the economy of a nation. Lourenco (2004) highlighted that economic development benefits can be measured in terms of the number of jobs created, the number of SMEs created, firm graduation rates and tax receipts as they are believed to be the major contribution to economic development.

Prochazkova (2015) concluded that business incubators can have a major impact on nations economic development through the enhancement of business ideas; innovation, raising of national competitiveness; reducing SMEs operational costs; new venture creation and SMEs survival and sustainability. Mansano and Pereira (2016) highlighted that business incubators can be used as mechanisms to stimulate innovation. While other benefits included the creation and growth of social and intellectual capital, where benefits are gained from participation in social events and in developing networks (Al Mubartaki et al., 2010; Lourenco, 2004; Clark and Minor, 2000). Scaramuzzi (2002) and Al Mubartaki et al., (2010) highlighted that business incubators can be used within any economy for the following objectives: 
Scientific Journal for Financial and Commercial Studies and Researches

(Vol.2, No.2 Part1, July 2021)

Dr. Hesham Magd and Dr. Aiman El Gharib

- New business formation - Business incubators are used to support the creation and formation of new business/ventures where jobs are created, create wealth, create innovative products/services and stimulate the flow of economic cycles

- Business stabilization - Business incubators can be used in aiding existing SMEs with their stability and their ability to operate without any challenges also reducing the risk of failure

- Business expansion and Sustainability - Business incubators can be used to aid existing SMEs to expand into different markets and improve operational efficiency, expanding production capabilities, hiring and managing labour and securing capital

- Commercialization of Research and knowledge - Business incubators can be used to commercialize research data and expertise

\section{Types of business incubators}

Mixed use incubators These types of incubators support and assist entrepreneurs and SMEs from different sectors/industries. They are created by the government to support economic development, growth and jobs creation (Al Mubartaki et al., 2020; Burger, 1999).

Technology

These types of incubators tend to support technologyincubators oriented SMEs and focus on how to combine technology and initial knowledge to result in improvement of 


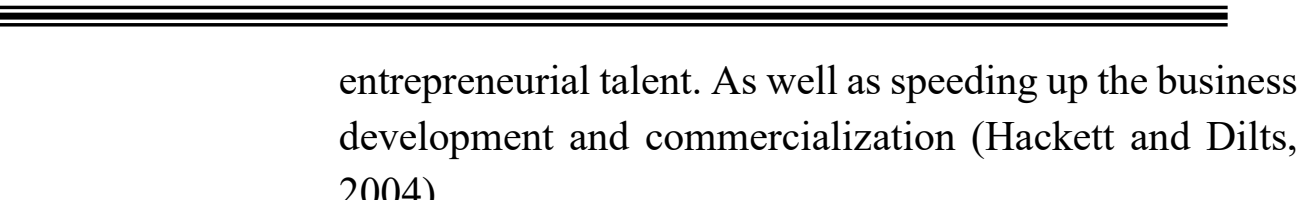
2004).

Manufacturing/Indus These types of incubators support and assist SMEs in the trial incubators manufacturing industry and tend to offer physical and production space and technical business assistance (Sanyal and Hisam, 2018; Al Mubartaki et al., 2010).

Targeted incubators These types of incubators focus on a focused industry or sectors such as food manufacturing, software development, multimedia, and may focus on specific demographics (Campbell, 2001; Al Mubartaki et al., 2010)

Empowerment/micro These types of incubators focus on supporting and enterprises/communi assisting targeted population where SMEs are created, ty incubators developed and nurtured (Al Mubartaki et al., 2010).

Virtual incubators These types of incubators offer support and assistance to those entrepreneurs and SMEs who are in different city and wish to maintain their offices and these incubators will offer advice through virtual platform (Van Tilburg et al., 2002; Bessant and Tidds, 2009) 
Al Mubartaki et al., (2010) indicated that business incubators reduce the risk of SMEs failure and $87 \%$ to $90 \%$ of all SMEs which graduated from business incubators are still in business, this indicates the impact of business incubators on business sustainability. Additionally, SMEs tend to have increased sales based on the support received from business incubators (NBIA, 2000). Moreover, Scaramuzzi (2002) has summarized the typical incubator resources and objectives that are applicable and practiced across the globe (see Figure 2) in reflection of what has been discussed above.

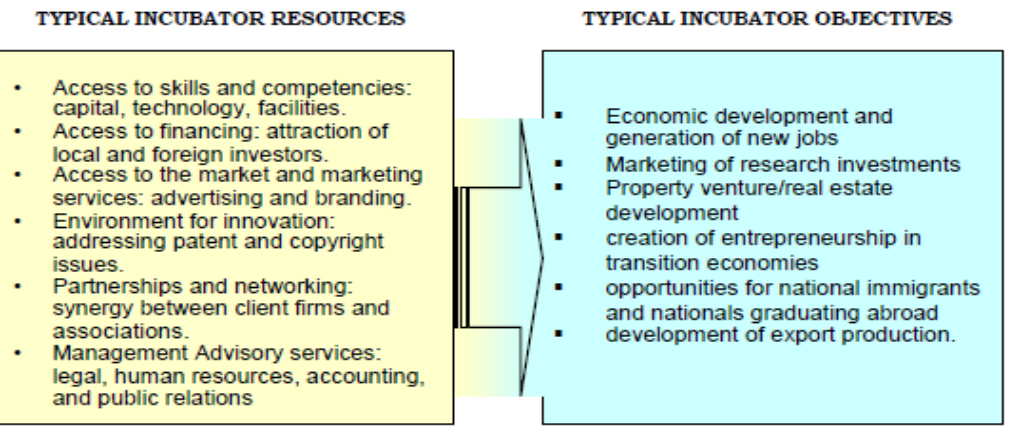

Figure 2: Typical incubator Resources and Objectives

(Source: Scaramuzzi, 2002: 5)

\section{BUSINESS INCUBATORS IN OMAN: CURRENT SCENARIO}

After careful investigation of the available business incubators in Oman, the authors compiled Figure 3 to illustrate the available business incubators.

Alrudha: According to their mission statement, Alrudha is a group of individuals who are looking to impact the Omani market and economy by aiding and supporting entrepreneurs in developing their entrepreneurial firms. Its mission is building working environments to help you succeed. It was established in April 2015 by Omar Al-Harthi and Fatma ALMukhaini for the purpose of providing services such as working space, events, workshops, and platform for investors. It also established the "ALhabta" event that brings together startups and investors to find financing and investment opportunities. In addition to organizing the "Start" event that aims to develop the capabilities of startups (ALRUDHA, 2020).

$$
r \cdot \varepsilon
$$


Oman Sail was established in 2008 by His Majesty Sultan Qaboos RIP for the purpose of establishing Muscat a destination hub for sailing and hosting international competition in this sport from across the globe. This will enable Oman to compete at different levels and bring the talent and creativity of the Omani youth, and in turn, this will help economic development (sail, 2020). In 2009, Oman Sail's Mohsin Al Busaidi became the first Arab to sail non-stop around the world, and The Wave, Muscat's Extreme Sailing team won the first of two successive. Currently, Oman Sail operates four Sailing Schools and has plans for three more by the end of 2020 (Kothaneth, 2020; Sail, 2020).

GlassPoint Innovation Spur: It was established in February 2009 by Rod MacGregor and Pete von Behrens to reduce the cost of solar thermal energy - bringing the solar collectors indoors. The purpose is to encourage small entrepreneurial to firms to focus on delivering and offering lowest cost solar energy products.

OTF Wadi Accelerator: OTF Wadi Accelerator is a seed stage fund and accelerator program, capitalized by the Oman Technology Fund, and powered by 500 startups. It was established in August 2018 by Oman Investment Fund (OIF) to support entrepreneurship by playing an integral role in supporting the growth of promising startups and emerging technologies in the MENA region and beyond. This program enhances and improves the probability of startups' success (Nair et al et al., 2017). Other services include:

- 3 months training program

- Mentorship

- Funding US $\$ 100 \mathrm{~K}$

- 10 startups per batch

$$
\text { r.o }
$$




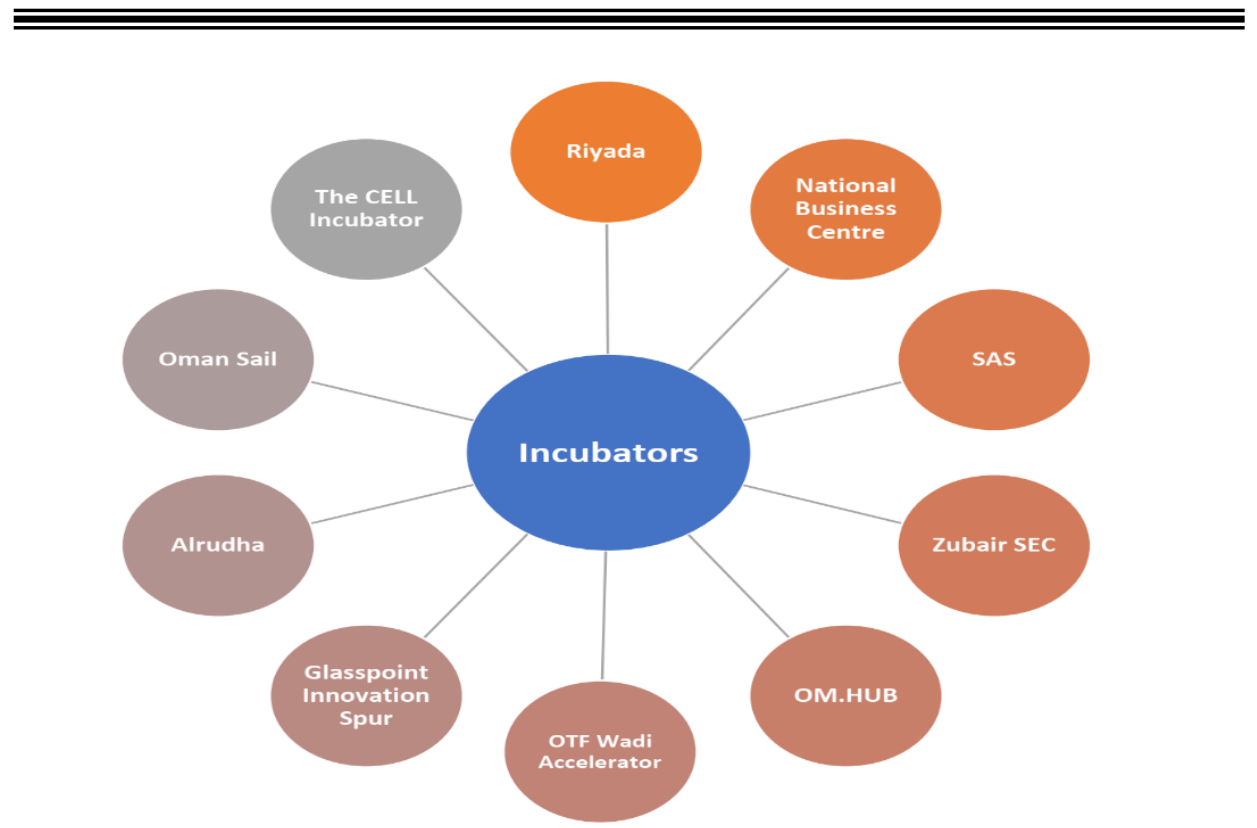

Figure 3: Available Business Incubators in Oman

(Source: Compiled by the Authors)

OM.HUB: The Sultanate now has a platform for developing and nurturing entrepreneurship. Called OM.HUB, the entrepreneurship platform. Its vision is creating a collaborative environment among stakeholders of the various platforms to support entrepreneurs. It was established in February 2018 by The National Business Centre (NBC) in cooperation with Oman Oil Company (OOC), Oman India Fertilizer Company (Omifco) and Oman Telecommunications Company (Omantel) to support the SME ecosystem by creating a super hub that caters to entrepreneurs at different levels from ideation to start ups to scaling up and high growth. OM.HUB adds tremendous value by creating a collaborative environment among stakeholders of the various platforms to support entrepreneurs. It also opens the door to entrepreneurs who would like to have a temporary location to start their business according to the following 
offer (OMIFCO, 2020). OM.HUB hosts 28 candidates and an open gathering area. OM. HUB offers various services to entrepreneurs such as workshops, awareness programs, facilities support, one on one business support sessions.

Riyada - Public Authority for SMEs: Al riyada was established under the Royal Decree No. 36/2013. It was founded to develop small and medium enterprises and to strengthen their contribution to Oman's economy and create employment. Riyada hopes to be a key pillar in creating jobs for the young youth in Oman through supporting SMEs, creating entrepreneurship culture, and enhance SMEs operations and offer support to SMEs and entrepreneurial firms (Mena Innovation, 2020).

National Business Centre: It was established in 2012 under the Public Establishment for Industrial Estate (Madayn). NBC was initiated to support Omani Entrepreneurs, startups and SMEs as it aims to be the premier platform to support and develop Omani entrepreneurs. The purpose of NBC is to advance business ideas into growing business and develop entrepreneurs and the economy. In turn NCB hope to achieve business sustainability, growth and job creation/employment. NBC supports entrepreneurs who are in the early stages of idea formation and others who are in advanced stages. NBC offers their consultant to work with entrepreneurs who are at the early stages of business idea formation and admit them to idea development workshop. NBC offers other services to advanced entrepreneurs such as financial, marketing, administrative advice, product/service branding workshops, and workshops/training on how to run small business.

SAS for Entrepreneurship: SAS was established by ITA Information Technology Authority (N.D). SAS is a leading fund for ICT entrepreneurs in Oman. SAS focus on also offering a physical and virtual platform

$$
r \cdot v
$$


environment for entrepreneurs. ITA and a wide range of committed and trusted partners, stakeholders and the application of global best practice will provide an inclusive and ICT-focused national business incubation environment through the SAS Program (ITA, 2020). SAS offers services such as space for entrepreneurs, consultancy, training and education, networking, and working relationship with the community. The objectives of SAS are:

- To develop and build a competitive IT industry in Oman

- To Provide new job opportunities/employment

- To Contribute in providing new services and local products in various IT fields

- To Develop Start-ups and SMEs

OMIFCO: By focusing on developing microbusinesses in accordance with the increasing number of youths entering the workforce each year, and the demands on the national economy to create additional opportunities for employment, the cell incubator was established by Oman India Fertilizer Company OMIFCO (N.D) as its CSR to support the creation of SMEs. OMIFCO collaborated with Al Jazeera Technical Solutions LLC \& Inspired Solutions Company to support entrepreneurship and Development of Micro business (OMIFCO, 2020). Its Commitment is Developing Oman's economy with special attention to the environment and the training of Omani youth (OMIFCO, 2020) through its entrepreneurial initiative as part of corporate social responsibility, where its employees are engaged with the community to develop and sustain the community economic situation. 
Zubair SEC: It was established by Zuabir Corporation in 2013 with the idea of supporting SMEs success and contribute towards a rapid change in the local business environment, where Zuabir becomes the hub for offering business solutions advise to help SMSs to succeed, grow, and penetrate other markets (Zubairsec, 2020).

In its current form, Zubair SEC is a professional body that remains commercially viable and successful due to the diversified knowledge it offers, its accumulated breadth of expertise, its high professionalism, and a global and local network including strategic partners. The Centre also continues to build on the strengths of The Zubair Corporation to lead positive change in the local business environment, supporting small businesses and providing for favorable initiatives in the Sultanate. Zubair SEC members have access to services which have been outstretched to them, such as; business development, capacity building, clinical solutionbased advisory, networking platforms, and a program which provides a financial grant for ten winners annually. These winners will also receive the benefit of business development, packaging, branding, product stabilization and intense advisory services. It was originated for the below benefits to Omani entrepreneurs:

- Access to business consultants, advisory experts and services

- Network opportunities with staff through suitable platforms, or in person

- Providing tools for management such as business plan templates, feasibility studies and organizational structure options

- Events to be held for SMEs developments such as training workshops, seminars and networking engagements

- Facilitating communication between fellow SMEs

- Providing access to the strategic partners of the incubators 
Scientific Journal for Financial and Commercial Studies and Researches

(Vol.2, No.2 Part1, July 2021)

Dr. Hesham Magd and Dr. Aiman El Gharib

- Pairing the benefits from local and national partners interested in supporting SMEs with preferred price(s) offers

- Facilitating communication between banks, traditional and nontraditional financial institutions and creditable businesses

- Providing financial grants for respective entrepreneurs

- Business development opportunities

The focus on developing business incubators in Oman is based on the pursuance of economic development through creating, developing and sustaining SMEs. It is believed that the development of business incubators in Oman have contributed positively to SMEs development, where this sector employs more than 200,000 which reflects $40 \%$ of the workforce (Riyada, 2018). The national GDP has benefited from SMEs by $20 \%$ annually which contributes positively to economic development (Al Abri et al., 2018). However, in comparison with developed markets, where SMEs workforce account for $50-60 \%$ and on average $50-55 \%$ GDP contribution, it is vitally important to expedite the growth of SMEs sector in Oman considering the limited employment opportunities in the governmental agencies for Omanis and also to scale down the reliance on the hydrocarbon sector (Sanyal and Hisam, 2018). However, in order to support entrepreneurship and SMEs development and growth, it's important to highlight some of the challenges faced by SMEs in Oman in order to be considered within the frameworks developed by the various business incubators available in Oman. There were various studies conducted (Al Barwani et al., 2014; Al Bulushi and Bagum, 2017; Al Maimani and Johari, 2015; Ashrafi et al., 2014; Atef and Al Balushi, 2015; Bilal and al Mqbali, 2015; Jansen, 2017; Magd and McCoy, 2014; Saqib et al., 2017; Talal, 2017), which highlighted the challenges of SMEs development and growth: 
Scientific Journal for Financial and Commercial Studies and Researches

(Vol.2, No.2 Part1, July 2021)

Dr. Hesham Magd and Dr. Aiman El Gharib

- Lack of business knowledge

- Lack of access to finance

- Lack of knowledge regarding trade policies and regulations

- Limited capacity to grow

- Lack of knowledge to utilize and incorporate technology for better results

- Lack of governmental support services/red tape

- Lack of circle of networks within the same field to work cooperatively

- Lack of financial and marketing knowledge to determine the viability of certain projects

It's clear that these challenges can be classified as the critical success factors for SMEs to grow and contribute further to economic development and therefore business incubators must focus on these challenges and incorporate them into their programs as the next stage of development phase of business incubators in Oman to achieve the vision regarding entrepreneurship development. On the other hand, we must also pay attention to the factors that contribute to the success of business incubators to ensure their sustainability. According to Lose et al. (2016), Buys and Mbewana (2007), and Ndabeni (2008) whom agreed on the following business incubators critical success factors "Access to science and technology expertise and facilities; Stringent selection criteria; Quality of entrepreneurs; Comprehensive business plan; Stakeholder support; Availability of funding; Competent and motivated management; Supportive government policies; Financial stability; Experienced advisory board; Networking; Policies and legal framework, and Society open to innovation" (Lose et al., 2016:135). Additional to these factors, Theodorakopoulos et al. (2014: 612) conducted an extensive literature review since mid-1980s on the success factors in business incubators and 
reached to the following factors "incubate selection policy; exit/graduation policy; shared office space and resources; incubator manager competences and relationship with incubates; support services such as management know how, advice on regulations; technology and RD support; networking; access to funding; monitoring performance".

Based on the comprehensive review of the critical success factors of business incubators, it's clear that there are some common success factors across studies which illustrate that these are the most reliable and valid critical success factors and they are:

- Stringent incubate selection criteria;

- Access to facilities and resources;

- Access to support service such as consultant and advisory services, networking; access to funding; legal advice;

- The availability of regulations and legal framework

- Quality of entrepreneurs (Motivation and Commitment)

- Monitoring performance;

- Acceptance of innovative products/services 
Based on this, it can be highlighted that critical success factors of business incubators will contribute to the success of business incubators and in turn will lead to entrepreneurship and SMEs sustainability and economic development. This can be illustrated in Figure 4.

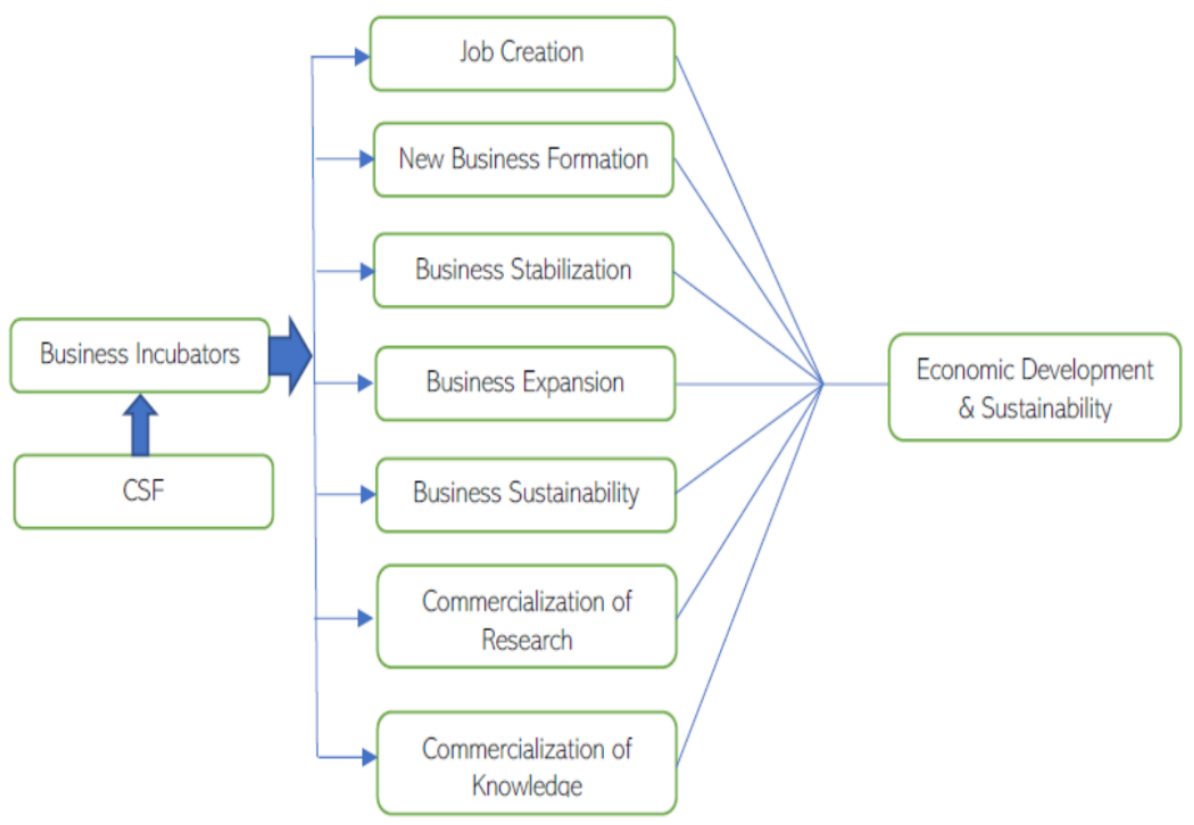

Figure 4: Business Incubators and Economic Development

Source: (Compiled by the authors as a conceptional model)

\section{CONCLUSION AND RECOMMENDATIONS}

Oman has recognized the importance of SMEs contribution to economic development and sustainability and designed the country's strategy based on the promotion of entrepreneurship and SMEs development by building a sustainable entrepreneurial ecosystem through business incubators. Business incubators contribute to the economy positively through job creation, creating, nurturing and sustaining SMEs, innovation, and raising national competitiveness. Small businesses do not 
survive or lack the growth potential and it is believed that business incubators would be able to enhance this sector further and as a result Oman has adopted business incubators. Business incubators in Oman are still in its early stages and this paper has discussed the available business incubators in Oman which have the potential to aid the sector. This paper has also revealed some of the challenges that faced SMEs such as lack of business knowledge; lack of access to finance; lack of knowledge regarding trade policies and regulations; and limited capacity to grow. These factors are classified as success factors for SMEs survival and growth, and the authors recommend that these critical success factors should be included with the business incubators available in Oman as part of their programs to aid entrepreneurs and SMEs.

In conclusion, it's fair to mention that business incubators play a crucial role in the development of entrepreneurship and SMEs, and it contributes to economic development and sustainability and Oman is no different. In order to attain economic development and sustainability, it's important that business incubators are successful in developing entrepreneurship and SME, and this can only occur if the business incubators adapts the highlighted critical success factors in the current study, such as stringent incubate selection criteria; access to facilities and resources; access to consultant, advisors, and experts; access to regulations and legal framework; selection of quality of entrepreneurs, performance measurement and acceptance of innovative products or services. 
Scientific Journal for Financial and Commercial Studies and Researches

(Vol.2, No.2 Part1, July 2021)

Dr. Hesham Magd and Dr. Aiman El Gharib

\section{REFERENCES}

Aernoudt, R. (2004), "Incubators tool for entrepreneurship", Small Business Economics, Vol. 23, No. 2, pp. 127-135

Al Abri, M., Rahim, A., Hussain, N. (2018), "Entrepreneurial ecosystem: An exploration of the entrepreneurship model for SMEs in Sultanate of Oman", Mediterranean Journal of Social Sciences, Vol. 9, No. 6, PP. 193-206

Al Barwani, K. M., Al Jahwari, M. R., Al Saidi, A. S., and Al Mahrouqi, F. S. (2014), Towards a growing, competitive and dynamic small and medium sized enterprises sector in Oman: Strategy and policies, Central Bank of Oman, London

Al Bulshi, B., and Bagum, S. (2017), "Growth strategies of SME in Oman: Issues and challenges", International Journal of Small Business and Entrepreneurship Research, Vol. 5, No. 2, pp. 21-61

Al Mubaraki, H. (2008), Procurement of international business incubation - quantitative and qualitative approaches, Melrose books, UK, www.melrosebooks.com

Al Mubaraki, H., Al Karaghouli, W., and Busler, M. (2010), "The creation of business incubators in supporting economic developments", European Mediterranean \& Middle Eastern Conference on Information Systems, April 12-13, Le Royal Meridien, Abu Dhabi

Al Mubaraki, H., and Busler, M. (2012), "Middle East towards incubator benefits: Case studies", International Journal of Social, Behavioral, Educational, Economic, Business and Industrial Engineering, Vol. 6, No. 3, PP. 344-347.

AlMaimani, J., and Johari, F. B. (2015), "Enhancing active participation of SMEs and Islamic Banks towards Economic Diversification in Oman", Procedia Economics and Finance, Vol. 31, pp. 677-688

Alrud'ha (2020), co-working space - community - solutions. Retrieved February 17, 2020, from https://www.alrudha.com/en

Ashrafi, R., Sharma, S. K., Al Badi, A. H., and Al Gharbi, K. (2014), "Achieving business success through information and 
communication technologies adoption by small and medium enterprises in Oman", Middle East Journal of Scientific Research, Vol. 22, NO. 1, pp. 138-146

Atef, T. M., and Al Balushi, M. (2015), "Entrepreneurship as a means for restructuring employment patterns", Tourism and Hospitality Research, Vol. 15, No. 2, pp. 73-90

Bessant, j., and Tidd, J. (2009), Innovation and entrepreneurship, $2^{\text {nd }}$ Edition, Chichester - John Wiley and sons Ltd, GB, pp. 255-297

Bilal, Z. O., and Al Mqbali, N. S. (2015), "Challenges and constrains faced by small and medium enterprises (SMEs) in Batinah governorate of Oman", World Journal of Entrepreneurship, Management and Sustainable Development, Vol. 11, No. 2, pp. 120-130

Burger, F. (1999), "Business incubators: How successful are they? Area Development online", Available online: www.areadevelopment.com/past/jan99/feature/incuba.htm.

Businessgateways (2020). More than 3,000 SMEs registered in Oman till the end of July. Retrieved at Feb $18^{\text {th }} .2020$ from https://businessgateways.com/news/2019/10/07/More-than-3000SMEs-registered-in-Oman-till-July

Buys, A. J. and Mbewana, P. N. (2007), @Key success factors for business incubation in south Africa: The Godisa case study", South African Journal of Science, Vol. 103, No. 9-10, pp. 356-358

Campbel, C. (1989), "Change agents in the new economy, business incubators and economic development", Economic Development Review, Vol. 7, No. 2, pp. 56-59.

Campbell, M. (2001), "A happy ending: Incubators offer nurturing environment for small business", available online: moreabcnews.90.com/sections/business/yourbusiness/smallbizbuild er010613.html.

Cha, M. and Bae, Z. (2010). The entrepreneurial journey: From entrepreneurial intent to opportunity realization. Journal of High Technology Management Research. Elsevier 
Deborah, M. and Kevin, M. (1995), "Economic and fiscal impacts of a business incubator", Economic Development Quarterly, Vol. 9, Issue 3.

Glasspoint (2020), ABOUT US. Retrieved from https://www.glasspoint.com/about-us/

Greene, P. and Butler, J. (1996), "The minority community as a natural business incubator", Journal of Business Research, Vol. 36, pp. 5158

Gundry, L. K., Ofstein, L. F., \& Kickul, J. R. (2014). Seeing Around Corners: How Creativity Skills in Entrepreneurship Education Influence Innovation in Business. The International Journal of Management Education.

ITA (2020). SAS overview. Retrieved at Feb $18^{\text {th }} .2020$ from https://www.ita.gov.om/ITAPortal/Pages/Page.aspx?NID=675\&PI $\mathrm{D}=2475 \& \mathrm{LID}=124$

Jansen, H. H., Blitterswjik, D., and Nieuwenhijsen, J. (2017), SME ecosystem in the sultanate of Oman, sensing and seizing opportunities in the tourism industry, Oman

Karimi, S., Biemans, H. J., Lans, T., Chizari, M. \& Mulder, M. (2014). The Impact of Entrepreneurship Education: A Study of Iranian Students' Entrepreneurial Intentions and Opportunity Identification. Journal of Small Business Management. Wiley Online Library

Kothaneth, L. (2018), OM.HUB platform launched to develop entrepreneurs. Retrieved February 18, 2020, from https://www.omanobserver.om/om-hub-launched-new-platformdevelop-entrepreneurs/

Kuratko, D. F. \& Hodgetts, R. M. (2004) Entrepreneurship: Theory, Process \& Practice, Thomson South-Western, UK

Kuratko, D. F. (2005) Entrepreneurship: The Emergence of Entrepreneurship Education: Development, Trends, and Challenges. Entrepreneurship Theory \& Practice. SAGE Publishing 
Laikaka, R. (1997), Lessons from international experience for the promotion of business incubation systems in emerging economies, Vienna: UNIDO

Lose, T., Nxopo, Z., Maziriri, E., Madinga, W. (2016), "Navigating the role of business incubators: A review on the current literature on business incubation in South Africa", ACTA Universitatis Danubius, Vol. 12, No. 5, pp. 130-140

Lourenco, M. S. (2004), "Understanding communications network development and business incubation: An analysis of three incubators in Louisville, Kentucky", A dissertation submitted to the faculty of the graduate school of the University of Louisville in partial fulfilment of the requirements for the Doctor of Philosophy

Madayn (2020). ABOUT NBC. Retrieved at Feb $18^{\text {th }} .2020$ from https://madayn.om/sites/NBC/EN/Pages/AboutUs.aspx

Magd, H. A., and McCoy, M. P. (2014), "Entrepreneurship in Oman: Paving the way for a sustainable future", Procedia Economics and Finance, Vol. 15, pp. 1632-1640

Mahmood, N., Jianfeng, C., Jamil, F., Karmad, J., and Khan, M. (2015), "Business incubators: Boon of boondoggle for SMEs and economics development of Pakistan", International Journal of u and e Service, Science and Technology, Vol. 8, No. 4, pp. 147-158.

Mansano, F., and Pereira, M. (2016), "Business incubators as support mechanisms for the economic development: Case of Maringa's technology incubator", International Journal of Innovation, Vol. 4, No. 1, pp. 23-32

Maroufkhani, P., Wagner, R., Khairuzzaman, W. \& Ismai, W. (2017). Entrepreneurial Ecosystems: A Systematic Review. Journal of Enterprising Communities: People and Places in the Global Economy, 12(4)

Mazzarol, T., (2014). Six Ways Governments Can Encourage Entrepreneurship. World Economic Forum 
Mena-innovation (2020), Riyada - Stakeholder. Retrieved at Feb $18^{\text {th }}$ .2020 from https://mena-innovation.com/2019/riyada-stakeholder/

Nair, V., Kothaneth, L., Yousuf, K., \& Mai Al Abri. (2017), OTF launches Wadi Accelerator Programme. Retrieved from https://www.omanobserver.om/otf-launches-wadi-acceleratorprogramme/

National Business Incubation association, NBIA, (2000), NBIA Publications, Available online - www.nbia.org

National Centre for Statistics \& Information. (2018), Statistical Year Book 2018, Muscat, Sultanate of Oman: National Centre for Statistics \& Information

Ndabeni, L. (2008), "The contribution of business incubators and technology stations to small enterprise development in South Africa", Development Southern Africa, Vol. 25, No. 3, pp. 259-268

Ogutu, V., and Kihonge, E. (2016), "Impact of business incubators on economic growth and entrepreneurship development", International Journal of Science and research, Vol. 5, No. 5, pp. 231-241

Omifco. (2020), ABOUT OMIFCO. Retrieved at Feb $18^{\text {th }} .2020$ http://www.omifco.com/about.html

Oxford Business Group. (2018), Balancing Act: Rising oil prices and economic diversification initiatives in Oman boost GDP growth and lower deficit. The report: Oman 2018, 33. Retrieved from Oxford Business Group

Prochazkovat, P., (2015), "Incubation activities and entrepreneurship: Does it work together?", Journal of Eastern Europe Research in Business \& Economics, Vol. 2015, DOI: 10.5171/2015, 436040

Riyada, (2018), Annual report 2017, Oman - Muscat Public Authority for SME development

Sail (2020), Retrieved February 18, 2020, from https://www.omansail.com/about-oman-sail/

Sanyal, S., and Hisam, M. (2018), "The role of business incubators in creating an entrepreneurial ecosystem: A study of the Sultanate of 
Oman", International Journal of Contemporary Research in Humanities and Social Sciences, Vol. 7, No. 1, pp. 60-77.

Saqib, M., Baluch, N. H., and Udin, Z. M. (2017), "Moderating role of technology orientation on the relationship between knowledge management and SMEs performance in Oman: A conceptual study", International Journal of Economic Perspectives, Vol. 11, No. 1, pp. $433-441$

Scaramuzzi, E., (2002), "Incubators in developing countries: Status and development perspectives", InfoDev Program, The World Bank, Washington, DC, 26637, pp. 1-35

Shalley, C. E., Gilson, L., \& Blum, T. C. (2009). Interactive Effect of Growth Need Strength, Work Context, and Job Complexity on SelfReported Creative Performance. The Academy of Management Journal

Shanfari, D. (2012), "Entrepreneurship in Oman: A snapshot of the main challenges", paper presented at the united nations conference on trade and development - multiyear expert meeting on enterprise development policies and capacity building in science, Geneva.

Talal, A R. (2017), Oman $9^{\text {th }}$ five year development plan and the strategic economic sectors - 2016-2020 - publication.: https://www.deutschoman.de

Theodorakopoulos, N., kakabdse, N., and McGowan, C. (2014)," What matters in business incubators? A literature review and a suggestion for situated theorizing", Journal of Small Business and Enterprise Development, Vol. 21, No. 4, PP. 602-622.

Wagner, K. (2006), "Business development incubator programs: An assessment of performance in Missouri", A dissertation presented in partial fulfilment of the requirement for the degree of Doctor of Philosophy, Capeila University

Zubairsec. (2020), OUR PROFILE. Retrieved at Feb $18^{\text {th }} .2020$ from https://zubairsec.org/who-we-are/our-profile/ 